\title{
Norway versus The Netherlands: will taTME stand the test of time?
}

\author{
S. Atallah ${ }^{1,2,3} \cdot$ P. Sylla ${ }^{4} \cdot$ S. D. Wexner ${ }^{5}$
}

Received: 1 September 2019 / Accepted: 19 September 2019 / Published online: 10 October 2019

(c) Springer Nature Switzerland AG 2019

Rectal cancer surgery has many important technical considerations, including the significant challenges of operating within a confined space with limited visibility and maneuverability. These problems are accentuated in patients with an elevated body mass index, android pelvis, bulky tumor, enlarged prostate, and fibrosis following neoadjuvant chemoradiotherapy. The general consensus is that such obstacles may potentially compromise oncologic adequacy by resulting in incomplete total mesorectal excision (TME) and/or positive resection margins.

The technique of transanal total mesorectal excision (taTME) provides potential solutions by allowing the mesorectum to be excised under magnification from both the abdominal and transanal fields. Accordingly, Heald referenced taTME as a solution to a problem [1]. In addition, assurance of an acceptable distal margin is addressed by direct visualization of the purse string suture placement prior to the start of the dissection. Predicated upon improved access and incumbent upon proper technique, taTME has yielded surprisingly good early results. Preliminary data from early adoption centers revealed that sphincter-preserving, "bottom-up" dissection matched, if not exceeded, historical oncologic metrics. Most notable were the low rates of positive circumferential and distal margins [2], as well as higher rates of complete and near-complete TME specimen grades [3], making the technique an appealing option for challenging tumors of the distal rectum $[4,5]$. These preliminary data were of particularrelevance in the setting of the ongoing debate regarding the oncologic non-inferiority of laparoscopic/robotic vs open TME [6-8]. Although

\footnotetext{
S. Atallah

atallah@post.harvard.edu

HCA North Florida Division, Oviedo, FL, USA

2 University of Central Florida, College of Medicine, Orlando, FL, USA

3 AdventHealth Winter Park, Winter Park, FL, USA

4 Mount Sinai Health System, New York, USA

5 Cleveland Clinic, Weston, FL, USA
}

criticized for non-validated data entry, the international taTME registry corroborated these favorable preliminary oncologic outcomes [9], even though, in aggregate, longterm oncologic results were lacking.

Despite the rapid globalization of taTME, adoption has been tempered by caution given the complexity of the procedure including a long learning curve, and the concerning reports detailing procedure-specific morbidity. These complications have included $\mathrm{CO}_{2}$ embolus, male urethral injury, and potential contamination secondary to purse string failure. Anastomotic leak rates, which were initially believed to be lower with taTME than with abdominal approaches, have been shown to be higher in the Dutch and International taTME registries, vis-à-vis leak rates reported in the COLOR II and CLASSIC trials. Perhaps due to the aforementioned reports, a taTME trial originating from Sahlgrenska University Hospital in Sweden and registered on clinicaltrials.gov has been suspended. Most concerning, in Norway, a widely publicized moratorium on taTME has been issued, substantiated by reports of higher than expected local recurrence rates.

The Norwegian report by Larsen et al. [10] describes a $9.5 \%$ local recurrence rate at a median follow-up of 11 months among 110 patients who had taTME for rectal cancer over a 3 -year period at (mainly) four hospitals. This rate-well in excess of the $3.4 \%$ rate of local recurrence from the Norwegian Colorectal Cancer Registry, and double the rate observed in COLOR II [11] - has prompted the nationwide cessation of taTME. In Norway, local failure data are likely to be accurately captured, because all local recurrences are referred to a single center-the Norwegian Radium Hospital in Oslo. Assuming that taTME cases were evenly distributed among the four participating hospitals over a 3-year period, the per center experience would equate to nine taTME cases per year which may not qualify as "high volume". Moreover, the pre-taTME experience of these surgeons with both laparoscopic TME and transanal endoscopic surgery was not stipulated; mastery of these skills is an important prerequisite to embarking upon taTME. 
While many case specifics are yet to be analyzed-including the use of neoadjuvant therapy, intraoperative complications such as perforation and purse string disruption, and postoperative morbidity such as anastomotic leaks and pelvic abscess-the article deserves attention. These cases of local recurrence which occurred early and with multifocal pelvic side wall involvement are atypical for local failure after traditional TME. Larsen et al. hypothesized that this phenomenon may be the direct consequence of transanal purse string failure. At least in theory, exfoliated tumor cells can either directly seed the resection bed or become aerosolized during taTME dissection. Despite the lack of scientific evidence to substantiate this hypothesis, the specter of technical inadequacy highlights the need for standardized education, training, and proctoring. To date, the Norway report stands in sharp contrast with all prior reports and observations on short-term oncologic outcomes of taTME. Notwithstanding, it has intensified the need for 3- and 5-year long-term oncologic outcomes of the procedure that was first described in 2009 [12].

In this issue of Techniques in Coloproctology, Hol et al. (Netherlands) are the first group to report on their 3- to 5 -year oncologic outcomes in one of the largest cohorts of patients who had taTME [13]. The study is perfectly timed, in immediate succession to the Norway moratorium. In this consecutive series of 159 patients, the 3- and 5-year local recurrence rates were $2 \%$ and $4 \%$, respectively, a local failure rate comparable to the $5 \%$ loco-regional recurrence rate observed in the COLOR II trial (for both open and laparoscopic TME) [11]. Furthermore, Hol et al. reported the disease-free survival rate at 5 years to be $81 \%$, an acceptable long-term outcome for locally advanced rectal cancer.

The discordance in oncologic outcomes between Norway and the Netherlands needs to be analyzed. Could this have been related to the fact that all taTME cases were centralized to a single center in the Netherlands, while results were pooled among four centers (or possibly more) in Norway? Are there factors specific to the implementation of taTME programs that could so drastically affect patient outcomes? The answers to these questions are difficult to elucidate since the Norway moratorium (reported as a lead article in The British Journal of Surgery), did not disclose pertinent case specifics. Thus, there is a dearth of data from which to draw any meaningful conclusions, leaving readers with more questions than answers. A plausible rationale could be variations in surgeon expertise and center volume. One clue suggesting the validity of this supposition is that local recurrence (but not distant failure) has been found to be significantly higher in low-volume taTME centers when compared to high-volume centers (8.9\% vs $2.8 \%$ ) [14]. It is conceivable that the technical quality of taTME dissection could impact oncologic outcome, and yet this critical variable cannot be measured by interpreting specimen quality and the often referenced surrogate markers of oncologic adequacy. Larsen et al. quite astutely state in their report, "local recurrences related to the rectal transection and air flow during dissection from the perineum cannot be evaluated by examining the specimen" [10].

While training pedagogies for taTME in Europe and North America have been remarkably well conceived and orchestrated $[15,16]$, there remain some deficits. The overtraining of surgeons who lack case volume is one example. In the United States more than 400 surgeons have received taTME training in preparation for implementing the operation; perhaps only 25 of whom could be considered "highvolume" rectal cancer surgeons. Thus, many surgeons may never gain a sufficient level of technical competency due to lack of volume. Another limitation of current taTME training paradigms is that there is a lack of structured proctoring and mentorship to assure successful implementation. Because of the complexity of the operation, most surgeons experienced with taTME concur that formalized proctoring should be an integral component along the training pathway, and that there is value in educating a dedicated OR team so that case flow and choreography are optimized.

An important parallel can be drawn from the early 1990s - when Berends et al. noted a $21 \%$ incidence of port site recurrence [17] - to today, when Norwegians have reported a prohibitively high local recurrence rate with taTME. The response to Berends' report included national moratoria on the performance of laparoscopic colorectal surgery for malignancy. In addition, the single report from Berends et al. and a few other case reports were of sufficient concern to prompt societies to create guidelines about the learning, implementation, and subsequent use of laparoscopic colorectal surgery. In the United States, the Society of American Gastrointestinal and Endoscopic Surgeons (SAGES) and the American Society of Colon and Rectal Surgeons (ASCRS) created a task force which presented and published a training schema [18]. In the United Kingdom, The National Training Program in Laparoscopic Colorectal Surgery (LAPCO) was developed to ensure appropriate training prior to performance of laparoscopic colorectal surgery. The implementation of taTME should be adopted under a similar framework. Ultimately, the outlier publications in which unacceptably high incidence of port site recurrences were reported, faded into the annals of surgical history as they were proven by time, trials, and data to be aberrations.

The next decade will likely show a continued use of taTME, although it should probably be used more selectively with more stringent selection criteria. All patients with rectal cancer should receive care from teams who specialize in and ideally perform high volumes of rectal cancer care. In the USA, these centers should ideally all become accredited by the American College of Surgeons Commission on 
Cancer National Accreditation Program for Rectal Cancer [19]. Training should be remodeled-with an emphasis on formal proctoring [20]. Ultimately, taTME should be maintained as a valid solution to the specific challenge of low pelvic dissection. In the near future, taTME collaborative studies including COLOR III and the North American Multicenter Phase II Study on Transanal TME are expected to clarify the expected norms for oncological outcomes on a more global scale. We believe that the adverse outcomes reported in Norway are avoidable by stringent patient selection, structured surgical training, and frequent performance of taTME within the context of high-volume specialty teams. We are optimistic that these potentially avoidable aberrant results will be relegated into the footnotes of future commentaries alongside the results of Berends et al., and that taTME will, in fact, stand the test of time.

\section{Compliance with ethical standards}

Conflict of interest Dr. Sam Atallah reports consultancy for Applied Medical, Inc., ConMed, Inc., Medtronic, and Auris Health. Dr. Steven Wexner reports consulting fees and royalties for intellectual property license from Intuitive Surgical, Medtronic, and Karl Storz, as well was consulting fees for Tigenix. Dr. Patricia Sylla reports grant support for the Phase II North American taTME Trial from Ethicon, Inc., Medtronic, Karl Storz, Stryker, Novadaq, Richard Wolf, Olympus, and Applied Medical, Inc.

Ethical approval This article does not contain any study of human participants or animals performed by any of the authors.

Informed consent For this article formal consent in not applicable.

\section{References}

1. Heald RJ (2013) A new solution to some old problems: transanal TME. Tech Coloproctol 17(3):257-258. https://doi.org/10.1007/ s10151-013-0984-0

2. Denost Q, Adam JP, Rullier A, Buscail E, Laurent C, Rullier E (2014) Perineal transanal approach: a new standard for laparoscopic sphincter-saving resection in low rectal cancer, a randomized trial. Ann Surg 260:993-999

3. Velthuis S, Nieuwenhuis DH, Ruijter TE, Cuesta MA, Bonjer HJ, Sietses C (2014) Transanal versus traditional laparoscopic total mesorectal excision for rectal carcinoma. Surg Endosc 28:3494-3499

4. Lacy AM, Tasende MM, Delgado S, Fernandez-Hevia M, Jimenez M, De Lacy B, Castells A, Bravo R, Wexner SD, Heald RJ (2015) Transanal total mesorectal excision for rectal cancer: outcomes after 140 patients. J Am Coll Surg 221(2):415-423

5. Fernández-Hevia M, Delgado S, Castells A et al (2015) Transanal total mesorectal excision in rectal cancer: short-term outcomes in comparison with laparoscopic surgery. Ann Surg 261:221-227

6. Jayne D, Pigazzi A, Marshall H, Croft J, Corrigan N, Copeland J, Quirke P, West N, Rautio T, Thomassen N, Tilney H (2017)
Effect of robotic-assisted vs conventional laparoscopic surgery on risk of conversion to open laparotomy among patients undergoing resection for rectal cancer: the ROLARR randomized clinical trial. JAMA 318(16):1569-1580

7. Stevenson AR, Solomon MJ, Lumley JW, Hewett P, Clouston AD, Gebski VJ, Davies L, Wilson K, Hague W, Simes J (2015) Effect of laparoscopic-assisted resection vs open resection on pathological outcomes in rectal cancer: the ALaCaRT randomized clinical trial. JAMA 314(13):1356-1363

8. Fleshman J, Branda M, Sargent DJ, Boller AM, George V, Abbas M, Peters WR, Maun D, Chang G, Herline A, Fichera A (2015) Effect of laparoscopic-assisted resection vs open resection of stage II or III rectal cancer on pathologic outcomes: the ACOSOG Z6051 randomized clinical trial. JAMA 314(13):1346-1355

9. Penna M, Hompes R, Arnold S, Wynn G, Austin R, Warusavitarne J, Moran B, Hanna GB, Mortensen NJ, Tekkis PP, TaTME Registry Collaborative (2017) Transanal total mesorectal excision: international registry results of the first 720 cases. Ann Surg 266(1):111-117. https://doi.org/10.1097/SLA.0000000000 001948

10. Larsen SG, Pfeffer F, Kørner H, Norwegian Colorectal Cancer Group (2019) Norwegian moratorium on transanal total mesorectal excision. Br J Surg 106(9):1120-1121. https://doi. org/10.1002/bjs.11287

11. Bonjer HJ, Deijen CL, Haglind E, COLOR II Study Group (2015) A randomized trial of laparoscopic versus open surgery for rectal cancer. N Engl J Med 373(2):194. https://doi. org/10.1056/NEJMc1505367

12. Sylla P, Rattner DW, Delgado S, Lacy AM (2010) NOTES transanal rectal cancer resection using transanal endoscopic microsurgery and laparoscopic assistance. Surg Endosc 24(5):1205-1210. https://doi.org/10.1007/s00464-010-0965-6

13. Hol JC, van Oostendorp SE, Tuynman J, Sietses C (2019) Longterm oncological results after transanal total mesorectal excision for rectal carcinoma. Tech Coloproctol. https://doi.org/10.1007/ s10151-019-02094-8

14. Deijen CL, Tsai A, Koedam TW, Veltcamp Helbach M, Sietses C, Lacy AM, Bonjer HJ, Tuynman JB (2016) Clinical outcomes and case volume effect of transanal total mesorectal excision for rectal cancer: a systematic review. Tech Coloproctol 20(12):811-824

15. McLemore EC, Harnsberger CR, Broderick RC, Leland H, Sylla P, Coker AM, Fuchs HF, Jacobsen GR, Sandler B, Attaluri V, Tsay AT, Wexner SD, Talamini MA, Horgan S (2016) Transanal total mesorectal excision (taTME) for rectal cancer: a training pathway. Surg Endosc 30(9):4130-4135. https://doi. org/10.1007/s00464-015-4680-1

16. Veltcamp Helbach M, van Oostendorp SE, Koedam TWA, Knol JJ, Stockmann HBAC, Oosterling SJ, Vuylsteke RCLM, de Graaf EJR, Doornebosch PG, Hompes R, Bonjer HJ, Sietses C, Tuynman JB (2019) Structured training pathway and proctoring; multicenter results of the implementation of transanal total mesorectal excision (TaTME) in the Netherlands. Surg Endosc. https://doi.org/10.1007/s00464-019-06750-w

17. Berends F, Kazemier G, Bonjer H, Lange J (1994) Subcutaneous metastases after laparoscopic colectomy. Lancet 344(8914):58

18. Fleshman J, Marcello P, Stamos MJ, Wexner SD (2006) Focus Group on Laparoscopic Colectomy Education as endorsed by the American Society of Colon and Rectal Surgeons (ASCRS) and the Society of American Gastrointestinal and Endoscopic Surgeons (SAGES): guidelines for laparoscopic colectomy course. Surg Endosc 20(7):1162-1167

19. Wexner SD, Berho ME (2017) The rationale for and reality of the new national accreditation program for rectal cancer. Dis Colon Rectum 60(6):595-602 
20. Helbach MV, van Oostendorp SE, Koedam TW, Knol JJ, Stockmann HB, Oosterling SJ, Vuylsteke RC, de Graaf EJ, Doornebosch PG, Hompes R, Bonjer HJ (2019) Structured training pathway and proctoring; multicenter results of the implementation of transanal total mesorectal excision (TaTME) in the Netherlands. Surg Endosc 2019:1
Publisher's Note Springer Nature remains neutral with regard to jurisdictional claims in published maps and institutional affiliations. 